\title{
Splenic Pulp
}

National Cancer Institute

\section{Source}

National Cancer Institute. Splenic Pulp. NCI Thesaurus. Code C33603.

The parenchyma of the spleen, consisting of lymphocytes and macrophages. It lies between the splenic trabecula. Red pulp is the part suffused with blood and white pulp consists of areas of lymphatic tissue where there are sleeves of lymphocytes and macrophages. 